\title{
Lime soil conditioner based on soda production sludge for reclamation of industry-disturbed soils in the impact zone of an oil refinery
}

\author{
Elena Kalinina $^{1, *}$ and Larisa Rudakova $^{1}$ \\ ${ }^{1}$ Institute for Environmental Protection, Perm National Research Polytechnical University, 614990, \\ 29, Komsomolsky prospekt, Perm, Russia
}

\begin{abstract}
The paper presents the results of a study on the use of soda production sludge (SPS) as a lime soil conditioner. SPS with a less than 0.1 $\mathrm{mm}$ fraction is the most suitable in terms of physical, chemical, and toxicological properties and meets the requirements of GOST-14050-93 «Limestone (dolomite) dust. Specifications» on the content of the active substance, the mass fraction of calcium and magnesium carbonates. Reclamative properties of SPS were studied on soil samples taken in the territory removed from the sanitary protection zone of the oil refinery. It was found that all soil samples have a phytotoxic effect on pea seedlings. The introduction of SPS in amount of 1-3 g per $\mathrm{kg}$ of soil stimulates the development of the ground part and roots of oats and peas, and also increases the germination energy of oat and pea seeds in the initial soil samples by $2 \div 10$ times. The introduction of SPS into the samples of the studied soils at a dose of $1-3 \mathrm{~g} / \mathrm{kg}$ stimulates the development of colonies of Azotobacter bacteria and leads to an increase in the total number of soil microorganisms. The introduction of SPS in an amount of $3 \mathrm{~g}$ per kilo of soil leads to a slight increase in the environment reaction and an increase in the content of water-soluble salts in the soil up to 2 times. In view of this, it is necessary to control that the content of water-soluble salts does not exceed the established standards. Based on the results obtained, we consider it expedient to use soda production sludge as a lime soil conditioner and for the reclamation of industry-disturbed soils.
\end{abstract}

\section{Introduction}

An urgent issue is the reclamation and development of soils in the territories of abandoned industrial enterprises, on lands removed from the list of sanitary protection zones, and in settlements in areas adjacent to highways and industrial facilities.

Heavy metals (HM) and petroleum products are the main pollutants in urbanized areas. Soil pollution in the city of Perm is of a polyelemental nature, the priority pollutants are $\mathrm{Ni}$, $\mathrm{Pb}, \mathrm{Cu}, \mathrm{As}, \mathrm{Zn}$ and $\mathrm{Cr}$. [1], exceeding MAC up to 5 times. As a result of soil contamination with HMs and oil products, agrochemical and agrophysical characteristics of soils

\footnotetext{
*Corresponding author: kalininaelena1@rambler.ru
} 
deteriorate, and their phytotoxicity increases. HM and petroleum products negatively affect the biochemical processes in soil and its microbiocenosis.

In a number of works [2, 3], synecological indicators of soil microorganisms, enzymatic and functional activities were used to assess the ecological state of soils contaminated with HM. For biological monitoring, the use of Azotobacter genus of bacteria is recommended [4].

Studies [5] found that oil pollution increases the lysis processes of Azotobacter colonies, and deamination of amino acids and reduces the growth of microbial cells and their intensity in the medium, and therefore it is recommended to use bacteria of the genus Azotobacter to assess the quality of oil-contaminated soils.

1. Chemical reclamation - the introduction of lime and organic fertilizers into the soil $[6,7]$ - is an effective method to fight back the high soil pollution with HMs. The introduction of lime soil conditioners into soils leads to a decrease in the migration capacity of HMs [8,9] and contributes to an increase in all fractions of humic acids [3, 4].

2. According to the requirements of GOST 17.5.3.04-83 «Nature Conservation (SSOP). Lands. General requirements for land reclamation», reclamation of industrydisturbed soils includes measures for technical and biological reclamation, including the introduction of lime soil conditioners.

3. As soil conditioners cost high, the possibility of expanding the raw material base of soil conditioners, including use of industrial waste containing calcium carbonate $[8,9]$, is of great importance. Using waste assets allows reducing the consumption of primary natural resources and reducing the amount of industrial waste accumulation.

4. On the territory of the Perm Region, a technogenic source of calcium carbonate can be soda production sludge (SPS), which is formed during the production of soda ash by the Solvay ammonia process. Based on previously performed works, it was established that samples of SPS have a high sorption activity in the extraction of copper (II) and zinc ions from aqueous solutions [10].

5. The aim of this work is to assess the possibility of using soda production sludge as a lime soil conditioner for the restoration of industry-disturbed soils.

6. To achieve this goal, the following tasks were solved:

7. The physicochemical, physicomechanical and toxicological properties of soda production sludge and their compliance with the requirements for lime soil conditioners were studied.

8. The experimental assessment of the possibility of using soda sludge as a lime soil conditioner was carried out according to the following indicators: phytotoxicity based on oat and pea seedlings, toxicity based on the effect on Azotobacter, the effect of SPS on the total number of soil microorganisms.

\section{Materials and methods}

The studied object was the reclamative properties of soda production sludge. The subject of the study was the effect of soda production sludge on the phytotoxicity of soils and soil microorganisms.

The phase composition of SPS was studied using a Shimadzu XRD-700 X-ray diffractometer with software and databases.

Research of reclamative properties of SPS was carried out in accordance with the requirements of GOST-14050-93 «Limestone (dolomite) dust. Specifications».

The reclamative properties of SPS were determined by introducing SPS into the soil at various doses $(1,3,5 \mathrm{~g}$ per $\mathrm{kg}$ of soil).

The effect of SPS on plant and microbial communities when introduced into soil as a lime soil conditioner was studied by the following methods: phytotoxicity on oat and pea 
seedlings, toxicity of the effect on Azotobacter, and counting the total number of soil microorganisms by sowing.

For the studies, we used soil samples taken in the territory removed from the sanitary protection zone of the oil refinery while reducing its boundaries, the sampling points are shown in Fig. 1.

As a control reference sample, the fertile soil (FS) made according to technical specifications 0391-002-51540896-2002 was used.

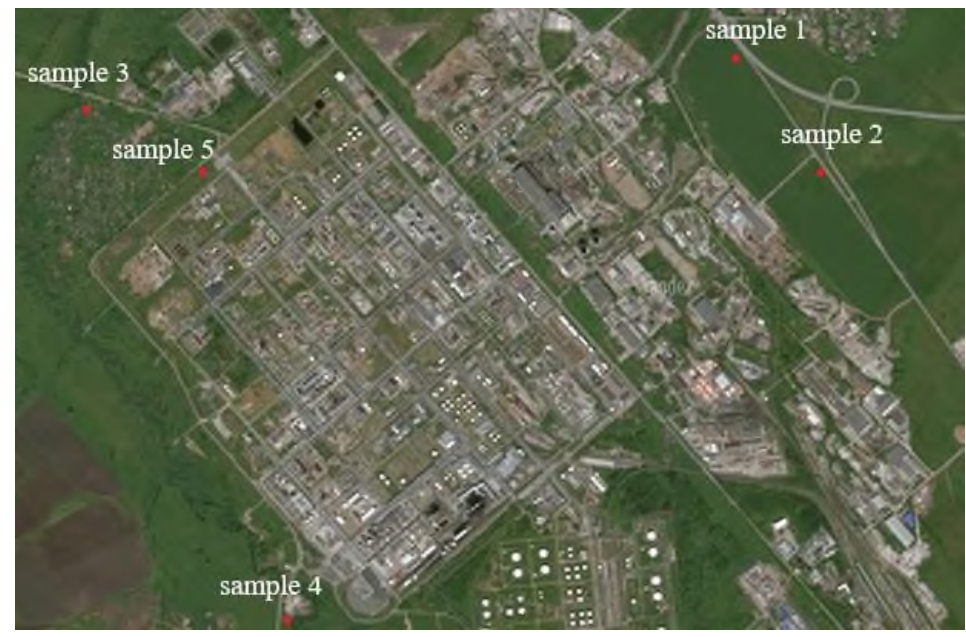

Fig. 1. Sampling points for soil samples in the territory removed from the sanitary protection zone of the oil refinery [https://yandex.ru/maps].

The studies of the properties of soil samples and SPS were carried out in accordance with the approved measurement procedures and methods presented in Table 1.

Table 1. Indicators, measurement procedure and research methods.

\begin{tabular}{|l|l|}
\hline \multicolumn{1}{|c|}{ Indicator } & \multicolumn{1}{c|}{ Measurement procedure, method } \\
\hline Soil samples selection & GOST 17.4.3.01-83, GOST 17.4.4.02-84 \\
\hline Soil density & GOST 5180-84, calculated \\
\hline Oil products content & $\begin{array}{l}\text { Environmental Regulatory Documents F (ERD F) } \\
14.1: 2: 4.168-2000, \\
\text { infrared spectrophotometry }\end{array}$ \\
\hline $\begin{array}{l}\text { Amount of water-soluble salts } \\
\text { in soil }\end{array}$ & GOST 17.5.4.02-84, gravimetric \\
\hline pH of water extract & ERD F 14.1:2:3:4.121-97, potentiometric \\
\hline & Soda production sludge \\
\hline $\begin{array}{l}\text { Amount of water-soluble salts } \\
\text { in soil }\end{array}$ & GOST 17.5.4.02-84, gravimetric \\
\hline pH of water extract & ERD F 14.1:2:3:4.121-97, potentiometric \\
\hline
\end{tabular}

\section{Results and discussion}

Lime soil conditioners are obtained by grinding or burning hard limestone rocks (limestone, dolomite, chalk) or using soft limestone rocks and various industrial wastes rich in lime for liming (Table 2). The use of waste as soil conditioners should be based on the preliminary 
results of studying their mineralogical content, particle size distribution and safety assessment of their physicochemical and toxicological properties.

Table 2. Characteristics of lime fertilizers [9].

\begin{tabular}{|l|c|c|c|}
\hline $\begin{array}{c}\text { Characteristics of } \\
\text { lime fertilizers }\end{array}$ & $\begin{array}{c}\text { Expressed as } \\
\mathrm{CaCO}_{3}, \%\end{array}$ & $\begin{array}{c}\text { Characteristics of } \\
\text { lime fertilizers }\end{array}$ & $\begin{array}{c}\text { Expressed as } \\
\mathrm{CaCO}_{3}, \%\end{array}$ \\
\hline \multicolumn{2}{|c|}{ Industrial lime fertilizers } & \multicolumn{2}{c|}{ Lime-rich industrial waste } \\
\hline Limestone dust & $80-85$ & Shale ash & $65-85$ \\
\hline Dolomite flour & 100 & Lime cake & $65-75$ \\
\hline \multicolumn{2}{|r|}{ Local lime fertilizers } & Cement dust & No less than 60 \\
\hline Calcareous tuff & $70-80$ & Metallurgical slags & $80-90$ \\
\hline Marl & $50-80$ & White lime slag & $50-68$ \\
\hline Peaty tuff & $10-50$ & Belite flour (sludge) & $45-50$ \\
\hline
\end{tabular}

It is known that the physicochemical and toxicological properties of SPS depend on the technologies of their dehydration and the terms and conditions of storage in sludge collectors. The safest [11] in terms of physicochemical and toxicological properties are finely dispersed (less than $0.1 \mathrm{~mm}$ ) practically non-hazardous SPS ( 5 hazard class for the environment) (Fig.2).

Hard limestone mainly contains $\mathrm{CaCO}_{3}$ and $\mathrm{MgCO}_{3}$, sand and clay. According to the content of $\mathrm{CaO}$ and $\mathrm{MgO}$, they are divided into three groups: limestones (contain 55-56\% $\mathrm{CaO}$ and up to $0.9 \% \mathrm{MgO}$ ), dolomitized limestones (contain $42-55 \% \mathrm{CaO}$ and $0.9-9.0 \%$ $\mathrm{MgO}$ ), dolomites (contain 30-32\% $\mathrm{CaO}$ and $18-20 \% \mathrm{MgO}$ ).

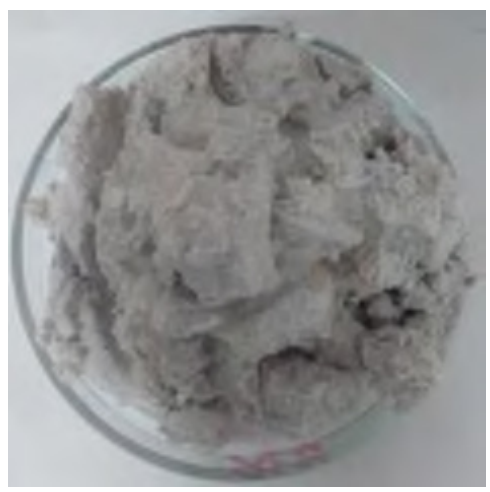

Fig. 2. SPS sample.

Based on the data of the X-ray diffraction pattern of the SPS sample (Fig. 3), it was established that the main crystalline phases forming the SPS are $\mathrm{CaCO} 3$ mineral Calcite $85 \%$ and $\mathrm{Ca}(\mathrm{OH}) 2$ mineral Portlandite $-15 \%$.

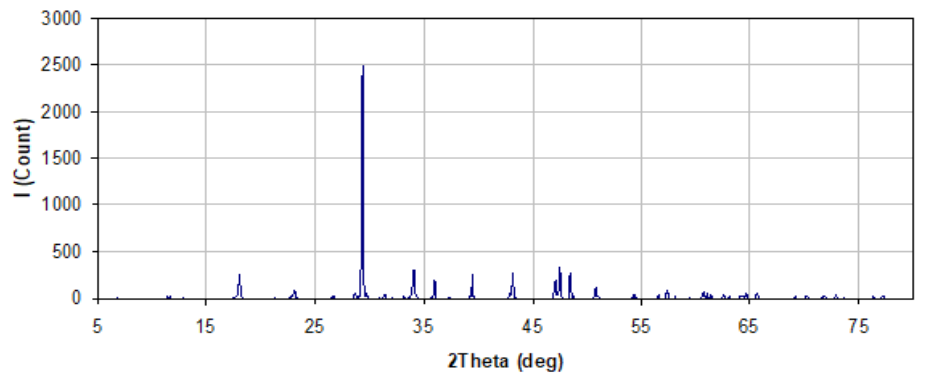

Fig. 3. X-ray diffraction pattern of the SPS sample. 
SPS meets the requirements of GOST - 140550-93 «Limestone (dolomite) dust. Specifications» in terms of indicators: mass fraction of calcium and magnesium carbonates, mass fraction of moisture, and content of an active substance (Table 3).

Table 3. Compliance of SPS properties with the requirements for soil conditioners.

\begin{tabular}{|l|c|c|}
\hline Indicator & $\begin{array}{l}\text { Requirements for } \\
\text { soil conditioners }\end{array}$ & $\begin{array}{l}\text { SPS } \\
\text { properties }\end{array}$ \\
\hline $\begin{array}{l}\text { mass fraction of calcium and magnesium } \\
\text { carbonates, \% }\end{array}$ & $80-85$ & $80.0-85$ \\
\hline mass fraction of moisture, \% & 1.5 & $1.0-1.4$ \\
\hline content of an active substance, \% & $74-81$ & $74-76$ \\
\hline
\end{tabular}

During the analysis of the selected soil samples, it was found (Table 4) that the soils belong to loamy and sandy loam types, are slightly acidic, the content of oil products in all samples does not exceed the established standard $(1.0 \mathrm{~g} / \mathrm{kg})$ in accordance with the Resolution of the Government of the Perm Region No. 813 - P of 20.12.18 «On approval of regional standards for the permissible residual content of oil and products of its transformation in the soils of the Perm Region after reclamation and other restoration work».

Table 4. Characteristics of the soil samples.

\begin{tabular}{|c|c|c|c|c|c|}
\hline Soil sample & No. 1 & No. 2 & No. 3 & No. 4 & No. 5 \\
\hline \begin{tabular}{|l|} 
Density \\
\end{tabular} & 1.09 & 0.9 & 1.06 & 0.90 & 0.93 \\
\hline $\begin{array}{l}\text { pH of water } \\
\text { extract, } \mathrm{pH}\end{array}$ & 6.1 & 6.3 & 6.3 & 6.3 & 6.3 \\
\hline $\begin{array}{l}\text { Oil products } \\
\text { content, mg/ } \\
\text { kg }\end{array}$ & 300 & 298 & 183 & 21,3 & 77,1 \\
\hline $\begin{array}{l}\text { Amount of } \\
\text { water- } \\
\text { soluble } \\
\text { salts, } \%\end{array}$ & 0.18 & 0.23 & 0.36 & 0.97 & 0.29 \\
\hline $\begin{array}{l}\text { Loss on } \\
\text { ignition, \% }\end{array}$ & 6.8 & 10.6 & 3.9 & 7.8 & 6.9 \\
\hline Type of soil & loamy & sandy loam & loamy & sandy loam & loamy \\
\hline $\begin{array}{l}\text { Land } \\
\text { category }\end{array}$ & $\begin{array}{l}\text { settlement } \\
\text { lands }\end{array}$ & settlement lands & settlement lands & agricultural lands & $\begin{array}{l}\text { settlement } \\
\text { lands }\end{array}$ \\
\hline $\begin{array}{l}\text { Sample } \\
\text { appearan } \\
\text { ce }\end{array}$ & & & & & \\
\hline
\end{tabular}

The dose of lime soil conditioner is selected with the condition of excluding soil alkalization. The introduction of a dose of SPS in the amount of $3 \mathrm{~g}$ per $\mathrm{kg}$ of soil leads to a slight increase in the environment reaction and increases the content of water-soluble salts in the soil by $1.2 \div 2.3$ times (Table 5 ).

Table 5. Effect of SPS on the environment reaction of the and the salinity of the water extract of soils.

\begin{tabular}{|l|c|c|c|c|}
\hline \multirow{2}{*}{ Sample } & \multicolumn{2}{|c|}{$\mathrm{pH}$ of water extract, } & \multicolumn{2}{c|}{$\begin{array}{c}\text { Content of water-soluble } \\
\text { shlts, \% }\end{array}$} \\
\cline { 2 - 5 } & soil & soil+SPS & soil & soil+SPS \\
\hline No.1 & 6.1 & 6.2 & 0.18 & 0.25 \\
\hline No.2 & 6.3 & 6.4 & 0.23 & 0.53 \\
\hline No.3 & 6.3 & 6.4 & 0.36 & 0.65 \\
\hline No.4 & 6.3 & 6.4 & 0.97 & 1.14 \\
\hline No.5 & 6.3 & 6.3 & 0.29 & 0.49 \\
\hline
\end{tabular}




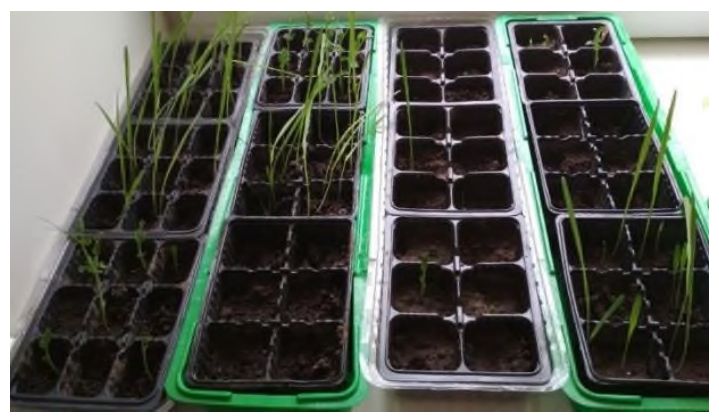

Figure 4. Experiment for phytotoxicity by seedling method.

In the initial soil samples, the absence of pea seeds sprouts was noted (Fig. 4), while in the fertile soil, peas germinated. The introduction of SPS in the amount of 1-3 g per $\mathrm{kg}$ of soil promoted growth of sprouts on the studied soil samples and in most cases led to an increase in the length of the ground and root parts of plants (Table 6).

Table 6. Effect of the dose of SPS application on the development of the ground parts of plants and roots.

\begin{tabular}{|c|c|c|c|c|c|c|c|c|c|}
\hline sample & \multicolumn{2}{|c|}{ Oat seed sprouts } & \multicolumn{2}{c|}{ Pea seed sprouts } & \multicolumn{2}{c|}{ Oat seed sprouts } & \multicolumn{2}{c|}{ Pea seed sprouts } \\
\cline { 2 - 10 } & $\begin{array}{c}\text { Ground part, } \\
\mathrm{cm}\end{array}$ & Root, cm & \multicolumn{2}{c|}{$\begin{array}{c}\text { Ground } \\
\text { part, cm }\end{array}$} & Root, cm & $\begin{array}{c}\text { Ground } \\
\text { part, cm }\end{array}$ & Root, cm & $\begin{array}{c}\text { Ground } \\
\text { part, cm }\end{array}$ & Root, cm \\
\hline \multicolumn{6}{|c|}{ Initial soil sample } & \multicolumn{5}{|c|}{ SPS, $3 / \mathrm{kg}$} \\
\hline 1 & 9.5 & 2.7 & - & - & 5.8 & 4.4 & 5.6 & 6 \\
\hline 2 & 7 & 5.5 & - & - & 7.5 & 3.7 & 2.6 & 3.4 \\
\hline 3 & 8.4 & 7.3 & - & - & 9.8 & 3.5 & 4.3 & 2 \\
\hline 4 & 4.1 & 6.4 & - & - & 16.4 & 8.3 & - & - \\
\hline 5 & 1.3 & 2 & - & - & 9.5 & 5.7 & 5.2 & 4.6 \\
\hline FS & 5.1 & 6.5 & 7.5 & 6.8 & 19 & 10.7 & - & - \\
\hline & & $S P S, 1 \mathrm{~g} / \mathrm{kg}$ & & & & $5 P S, 5 \mathrm{~g} / \mathrm{kg}$ & \\
\hline 1 & 9.8 & 2 & 5.8 & 5.2 & 4 & 3 & 1.3 & 1.1 \\
\hline 2 & 7.2 & 1.3 & 6.2 & 4.5 & 2.4 & 2 & 1 & 8 \\
\hline 3 & 3.4 & 2.7 & 4.5 & 5.3 & 1.8 & 2.5 & 3.8 & 5.3 \\
\hline 4 & 16.8 & 8.1 & 7.6 & 8 & 18.9 & 7.9 & 6.4 & 4.5 \\
\hline 5 & 13.3 & 1.6 & 54 & 6.2 & 13.8 & 6.1 & 5 & 4.3 \\
\hline FS & 17.4 & 10.8 & 14 & 7 & 17.3 & 10 & - & - \\
\hline
\end{tabular}

According to the results of the study of phytotoxicity by the method of seedlings, it was found that the introduction of SPS in an amount of 1-3 g per $\mathrm{kg}$ of soil increases the germination energy of oat and pea seeds in the initial soil samples by $2 \div 10$ times.

A study on the effect of SPS on Azotobacter (Fig. 5) revealed that SPS at a dose of 1-3 $\mathrm{g} / \mathrm{kg}$ stimulates the development of Azotobacter bacteria colonies (by 3 times). With the introduction of SPS, the total number of soil microorganisms increases (Fig. 6). 


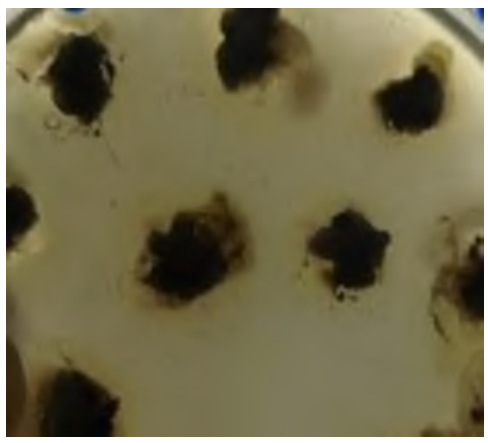

Fig. 5. Azotobacter bacteria colonies.

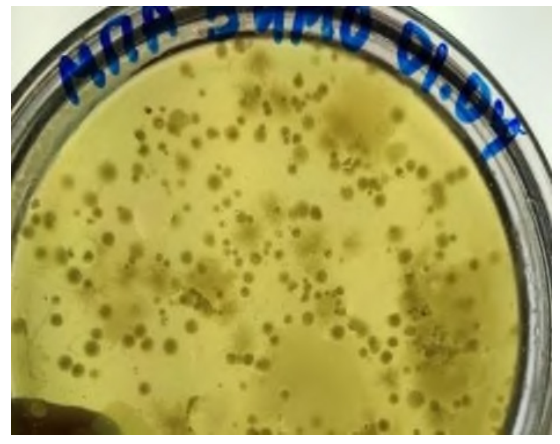

Fig. 6. Determination of the total number of colony-forming units in $1 \mathrm{~g}$ of soil.

\section{Conclusion}

1. Taking into account the granulometric, physicochemical and toxicological properties of soda production sludge, the expediency of using finely dispersed (less than $0.1 \mathrm{~mm}$ ) practically non-hazardous SPS (5 hazard class for the environment) as a lime soil conditioner has been established.

2. SPS meet the requirements of GOST-14050-93 «Limestone (dolomite) dust. Specifications».

3. The introduction of SPS in the amount of $3 \mathrm{~g}$ per $\mathrm{kg}$ of soil leads to a slight increase in the environment reaction and increases the content of water-soluble salts in the soil up to 2 times.

4. Initial soil samples taken in the territory removed from the sanitary protection zone of the oil refinery while reducing its boundaries, are phytotoxic for pea seeds sprouts. The introduction of SPS in the amount of 1-3 $\mathrm{g}$ per $\mathrm{kg}$ of soil promotes the emergence of seedlings on the studied soil samples and in most cases leads to an increase in the length of the ground and root parts of plants.

5. The introduction of SPS in the amount of 1-3 g per $\mathrm{kg}$ of soil increases the germination energy of oat and pea seeds in the initial soil samples by $2 \div 10$ times.

6. The introduction of SPS soil samples at a dose of $1-3 \mathrm{~g} / \mathrm{kg}$ stimulates the development of Azotobacter bacteria colonies and leads to an increase in the total number of soil microorganisms.

7. Based on the results obtained, we consider it expedient to use soda production sludge as a lime soil conditioner.

This work is funded by Ministry of science and higher education of the Russian Federation (Project № FSNM-2020-002 «Development of scientific basis for environmentally friendly and natureinspired technologies and environmental management in petroleum industry»).

\section{References}

1. A.A. Vasiliev, E.S. Lobanova, Ecological and geochemical assessment of Perm soil cover: heavy metals and arsenic, Perm agric. 1 (9), 34-49 (2015)

2. Yu.N. Vodyanitsky, A.A. Vasiliev, E.S. Lobanova, Contamination with heavy metals and metalloids of Perm soils, Agrochemistry 4, 60-68 (2009) 
3. A.A. Okolelova, V.F. Zheltobryukhov, G.S. Egorova, Ecological soil science and environmental laws, Volgograd: Volgograd state technical University Press 218 (2017)

4. E.S. Gasanova, A.N. Kozhokina, K.E. Stekolnikov, Changes in the parameters of PPK and humus state of leached Chernozem during long-term fertilization and liming, Bul. of the Voronezh st. agr. Un. 4(59), 13-21 (2018)

5. I.M. Malynovska, Effect of heavy metal ions on the number and activity of Azotobacter and melaninsynthesizing micromycetes, Biotechnol. Acta T 10, 3, 65-71 (2017)

6. A.V. Lednev, A.V. Lozhkin, G.A. Pozdeyev, Remediation of agro-podzolic soil contaminated with Nickel, Rus. Agricul.1 sci. 6, 31-35 (2019)

7. E.V. Egorova, Ecological and biological assessment of ameliorants for detoxification of soils contaminated with heavy metals, Prob. of Agrochem. and ecol. 1, 55-62 (2010)

8. M.M. Dyldaev, Ecological state of green areas and plantings within urbanized territories of the Kyrgyz Republic, Sci. and new technol. 3, 120-122 (2012)

9. M.A. Kuzmich, Agroecological justification of the use of non-traditional chemical meliorants in agriculture in Russia, dis. Doc. of agricul. Sci. (Moscow, 2004)

10. I.S. Glushankova, E.V. Kalinina, E.N. Demina, Modified sorbents based on soda production sludge for extracting ions of heavy metals from aqueous solutions waste water, Theor. and Appl. Ecol. 3, 100-108 (2018)

11. E.V. Kalinina, I.S. Glushankova, L.V. Rudakova, D.O. Sabirov, Obtaining a modified sorbent based on soda production sludge for liquidation of oil and oil products spills from the water surface, Ecol. and Ind. of Rus. V 22, 5, 30-35 (2018) 